\title{
Effect of Low Impact Aerobic Exercise on Functional Balance and Quality of Life in Type 2 Diabetes Mellitus Patients.
}

\author{
Peni Hardjanti ${ }^{1}$, Bayu Santoso ${ }^{1}$, Nuniek Nugraheni ${ }^{1}$, Agung Pranoto ${ }^{2}$ \\ ${ }^{1}$ Department of Physical Medicine and Rehabilitation, Dr. Soetomo General Hospital Surabaya \\ Indonesia \\ ${ }^{2}$ Department of Internal Medicine, Dr. Soetomo General Hospital Surabaya Indonesia
}

\begin{abstract}
:
Objectives: To determine the effect of low impact aerobic exercise on functional balance and the quality of life in type 2 Diabetes Mellitus (DM) patients

Methods: This is an experimental study. Participants were recruited from outpatient Diabetes Clinic in Dr. Soetomo General Hospital, Surabaya, Indonesia. Subjects of this study are men and women aged 3070 years whose diagnosed with type $2 \mathrm{DM}$, with A1c less than $10 \%$, have been using oral anti diabetic drug or subcutaneous insulin less than 30 IU daily, blood glucose level before exercise less than 250 $\mathrm{mg} \%$, and Berg Balance Scale between 41-56. Subjects were randomized into 2 groups with 38 subjects in the exercise group and 37 in the control group. The exercise group followed 25-30 minutes diabetic aerobic low impact exercise 3 times a week for 3 months, while the control group did not. Functional balance and quality of life before and after exercise were assessed using Berg Balance Scale (BBS) and the Sickness Impact Profile (SIP) questionnaire. Difference in BBS and quality of life improvement measured by SIP questionnaire were analyzed after 3 months of exercise.

Results: Mann Whitney test showed significant difference of the total score of BBS in the exercise group ( $\mathrm{p} 0.02 ; \alpha<0.05$ ). Chi Square test revealed significant improvement in four of the twelve parameters of the quality of life: sleep and rest (SR) (p 0.044), body care and movement (BCM) (p 0.017), ambulation (A) (p 0.001), and work (W) (p 0.000) in the exercise group.

Conclusions: Low impact aerobic exercise in type 2 Diabetes Mellitus patients may improve functional balance and the SR, BCM, A, and $\mathrm{W}$ parameters of the quality of life.
\end{abstract}

Key words: Low impact aerobic exercise, type 2 diabetic mellitus, functional balance, quality of life.

\section{INTRODUCTION}

People suffered from Diabetes Mellitus have been increasing rapidly on every decade, from 110,4 millions in 1994 to 175,4 millions in 2000 and will be 239,3 millions in 2010 . Which

Received in March 2013 and accepted for published in April 2013.

Correspondence email: Peni Hardjanti, peni.rudiananda@gmail.com means increase from 1,5 times in 2000 to twice in 2010. In Indonesia, population of diabetic patients are 2,5 millions in 1994, becomes 4 millions in 2000 and became 5 millions in $2010 .^{1}$

Common causes of this increasing prevalence are lifestyle changing, increasing calories intake, and less physical exercise. It is proved by difference prevalence of diabetics between rural and urban population. ${ }^{2}$

Peripheral nerve damage occur in about $25 \%$ of diabetic patients after had beed diagnosed, and become $50 \%$ after 20 years. 
As a consequence, many diabetic patients have a deficit on tactile sensitivity, sensation of vibration, lower extremity proprioception and kinesthesia. Sensation lost by peripheral neuropathy may have a role on balance disturbance, change of gait pattern, and increase fall risk. ${ }^{3,4}$

Regular physical exercise have known over the years as an important part in dealing with type 2 DM. Exercise can improve cell sensitivity to insulin and help lowering and maintaining body weight in obese patients. Regular exercise can also help control blood sugar level, and improve A1c. Exercise, diet and pharmacological therapy together play important role in the treatment to control blood glucose and decrease risk factor of cardiovascular problems. ${ }^{5,6}$

Regular physical exercise may improve physical health by improving cardiovascular system, respiration, and controlling blood sugar. But it also has psychological benefit in which the patients will feel fresh, have lower anxiety level about the illness, increase happiness, and self confidence, and in the end will result in increasing quality of life. ${ }^{5,6}$

Indonesian Diabetic Exercise which developed by Persatuan Diabetes Indonesia (Persadia), ${ }^{6}$ have been done routinely in Endocrinology Section, Department of Internal Medicine, Dr. Soetomo General Hospital Surabaya Indonesia. Beside its general benefits as mentioned above, its effect on improving functional balance which maybe impaired due to neuropathy complication and its benefit in improving quality of life need to be studied further. For that reason, this study was done.

\section{METHODS}

\section{Research Design}

This is an experimental study that took place in outpatient clinic, Dr. Soetomo General Hospital Surabaya Indonesia, from February to May 2007.

Study population was type $2 \mathrm{DM}$ patients who visited outpatient clinic of Endocrinology Section of Internal Medicine Department, Dr. Soetomo General Hospital Surabaya Indonesia.

Sample size was obtained by using equation below: ${ }^{7}$

$n 1=n 2=\frac{2(Z \alpha+Z \beta)^{2} \cdot S^{2}}{(X 1-X 2)^{2}}$

$=\frac{2(1,96+1,28)^{2} \cdot 2,42^{2}}{(9,36-7,488)^{2}}=35$

The inclusion criteria are type 2 Diabetes Mellitus (DM); age 30-70 years old; ability to under stand, follow and execute command, consuming anti diabetic drugs or insulin not more than $30 \mathrm{IU} /$ day; fasting blood sugar level (before exercise) less than $250 \mathrm{mg} \%$; A1c level less than 10\%; Berg Balance Scale between 41-56; DM with hemiparesis/ hemiplegic; with complications of cardiovascular, retinopathy, ulcus, nephropathy; using diuretic or betablocker; Hypertension with blood pressure more than 140/90; and participating on physical exercise 6 month before, more than twice a week, minimum 20 minutes for each section.

Subject are dropped out if they attend exercise session 3 times during study, and don't come on the last evaluation.

\section{RESULTS}

\section{Patient general characteristics}

As much as 80 subjects with type $2 \mathrm{DM}$ whose meet the inclusion criteria were randomized into 2 groups of exercise and control (40 subjects in each group). From the exercise group, 2 patients were dropped out (one didn't attend exercise session more than 3 times, and the other suffered from broken clavicle), while in the control group, 3 patients were dropped out (one because of undergoing cataract operation and the other two didn't attend to the final evaluation). 
Table 1. Patients General Characteristics

\begin{tabular}{cccc}
\hline Mean & \multicolumn{3}{c}{ Group } \\
\cline { 2 - 4 } & $\begin{array}{c}\text { Exercise } \\
\mathbf{n = 3 8}\end{array}$ & $\begin{array}{c}\text { Control } \\
\mathbf{n = 3 7}\end{array}$ & $\mathbf{p}$ \\
\hline age (year) & $55.58 \pm 7.299$ & $57.00 \pm 7.197$ & $<0.0001$ \\
Gender & & & \\
Male & $17.5 \%$ & $32.5 \%$ & 0.121 \\
Female & $82.5 \%$ & $67.5 \%$ & \\
Suffer DM (years) & $78 \pm$ & $7.43 \pm$ & 0.802 \\
& 6.995 & 6.39 &
\end{tabular}

Mean age for the exercise group is 55,58 years old, while in the control group is 57,00 years old, but this difference were not significant (table 1).

Both male or female can suffer from Diabetes Mellitus but there is a tendency that female is predominant (table 1). There is no significant difference between gender proportion in the two groups.

Period of suffering DM was established from the first diagnosis. The actual period is unknown. The mean period is 7,80 years in the axercise group and 7,43 years in the control group. There is no significant difference between the two groups (table 1).

Table 2. Mean of A1c level and A1c Improvement

\begin{tabular}{lccccc}
\hline & \multicolumn{5}{c}{ Paired Differences } \\
\cline { 2 - 5 } & $\begin{array}{c}\text { Exercise } \\
(\mathbf{n = 3 8 )}\end{array}$ & SD & $\begin{array}{c}\text { Control } \\
(\mathbf{n}=\mathbf{3 7})\end{array}$ & SD & $\mathbf{p}$ \\
\hline A1c (\%) & 7.14 & 1.479 & 6.99 & 0.975 & 0.622 \\
A1c Impr (\%) & 1.21 & 1,06 & -0.09 & 1.12 & 0.000 \\
\hline $\mathrm{P}<0.05$ & & & & &
\end{tabular}

In the baseline measurement, there was no significant difference in A1c between the two groups. A1c level in the exercise group was higher compared with control group $(7.14 \%$ vs
$6.99 \% ; \mathrm{p}=0.622)$

At the end of the study, there was a significant improvement in A1c level in the exercise group (table 2, figure 1).

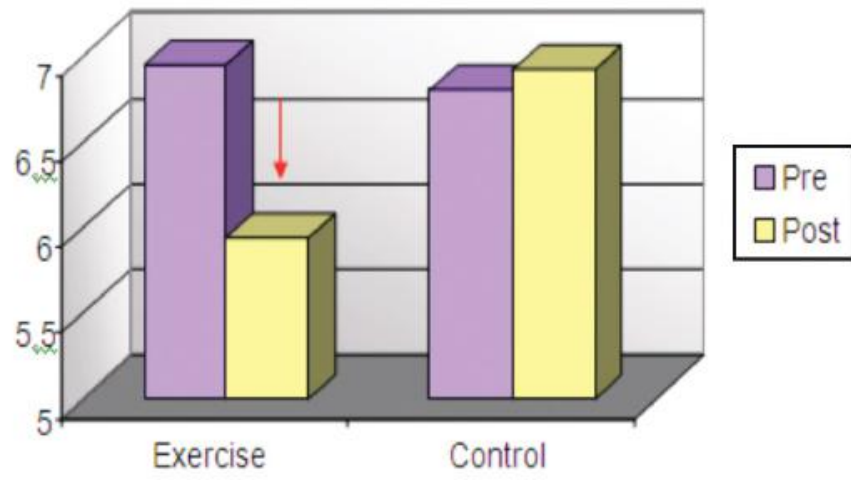

Figure 1. Mean of Improvement in A1c Level 


\section{Berg Balance Scale (BBS)}

At baseline, measurement of BBS (Balance task, BT) showed no significant difference between exercise and control group ( $\mathrm{p}>0.01)$.

After the intervention, the exercise group gained significant improvement at $\mathrm{BT}_{8}$ (reaching forward with outstretched arm) and $\mathrm{BT}_{14}$ (standing on one foot), compared to the control group (table 3 ).

Table 3. Improvement in Each Balance Task from Exercise to Control Group

\begin{tabular}{|c|c|c|c|c|c|}
\hline $\begin{array}{l}\text { Balance Task } \\
\text { (BT) }\end{array}$ & Group & $\begin{array}{c}\text { Mean of } \\
\text { rank }\end{array}$ & $\begin{array}{l}\text { Sum of } \\
\text { Rank }\end{array}$ & $\begin{array}{c}\text { Mann- } \\
\text { Whitney U }\end{array}$ & $\mathbf{P}$ \\
\hline$\overline{\mathrm{BT}_{1}}$ & $\begin{array}{l}\text { Exercise } \\
\text { Control }\end{array}$ & $\begin{array}{l}38,00 \\
38,00\end{array}$ & $\begin{array}{l}1444,00 \\
1406,00\end{array}$ & 703,00 & 1,000 \\
\hline $\mathrm{BT}_{2}$ & $\begin{array}{l}\text { Exercise } \\
\text { Control }\end{array}$ & $\begin{array}{l}38,00 \\
38,00\end{array}$ & $\begin{array}{l}1444,00 \\
1406,00\end{array}$ & 703,00 & 1,000 \\
\hline $\mathrm{BT}_{3}$ & $\begin{array}{l}\text { Exercise } \\
\text { Control }\end{array}$ & $\begin{array}{l}38,00 \\
38,00\end{array}$ & $\begin{array}{l}1444,00 \\
1406,00\end{array}$ & 703,00 & 1,000 \\
\hline $\mathrm{BT}_{4}$ & $\begin{array}{l}\text { Exercise } \\
\text { Control }\end{array}$ & $\begin{array}{l}38,00 \\
38,00\end{array}$ & $\begin{array}{l}1444,00 \\
1406,00\end{array}$ & 703,00 & 1,000 \\
\hline $\mathrm{BT}_{5}$ & $\begin{array}{l}\text { Exercise } \\
\text { Control }\end{array}$ & $\begin{array}{l}38,00 \\
38,00\end{array}$ & $\begin{array}{l}1444,00 \\
1406,00\end{array}$ & 703,00 & 1,000 \\
\hline $\mathrm{BT}_{6}$ & $\begin{array}{l}\text { Exercise } \\
\text { Control }\end{array}$ & $\begin{array}{l}38,00 \\
38,00\end{array}$ & $\begin{array}{l}1444,00 \\
1406,00\end{array}$ & 703,00 & 1,000 \\
\hline $\mathrm{BT}_{7}$ & $\begin{array}{l}\text { Exercise } \\
\text { Control }\end{array}$ & $\begin{array}{l}38,00 \\
38,00\end{array}$ & $\begin{array}{l}1444,00 \\
1406,00\end{array}$ & 703,00 & 1,000 \\
\hline $\mathrm{BT}_{8}$ & $\begin{array}{l}\text { Exercise } \\
\text { Control }\end{array}$ & $\begin{array}{l}41,30 \\
34,61\end{array}$ & $\begin{array}{l}1569,50 \\
1280,50\end{array}$ & 577,50 & $0,043^{*}$ \\
\hline $\mathrm{BT}_{9}$ & $\begin{array}{l}\text { Exercise } \\
\text { Control }\end{array}$ & $\begin{array}{l}40,83 \\
35,09\end{array}$ & $\begin{array}{l}1551,50 \\
1298,50\end{array}$ & 595,50 & 0,137 \\
\hline $\mathrm{BT}_{10}$ & $\begin{array}{l}\text { Exercise } \\
\text { Control }\end{array}$ & $\begin{array}{l}38,38 \\
38,38\end{array}$ & $\begin{array}{l}1444,00 \\
1406,00\end{array}$ & 703,00 & 1,000 \\
\hline $\mathrm{BT}_{11}$ & $\begin{array}{l}\text { Exercise } \\
\text { Control }\end{array}$ & $\begin{array}{l}40,92 \\
35,00\end{array}$ & $\begin{array}{l}1555,00 \\
1295,00\end{array}$ & 592,00 & 0,113 \\
\hline $\mathrm{BT}_{12}$ & $\begin{array}{l}\text { Exercise } \\
\text { Control }\end{array}$ & $\begin{array}{c}40,86 \\
35,7\end{array}$ & $\begin{array}{l}1552,50 \\
1297,50\end{array}$ & 594,50 & 0,105 \\
\hline $\mathrm{BT}_{13}$ & $\begin{array}{l}\text { Exercise } \\
\text { Control }\end{array}$ & $\begin{array}{l}38,01 \\
37,99\end{array}$ & $\begin{array}{l}1444,50 \\
1405,50\end{array}$ & 702,50 & 0,985 \\
\hline $\mathrm{BT}_{14}$ & $\begin{array}{l}\text { Exercise } \\
\text { Control }\end{array}$ & $\begin{array}{l}43,34 \\
32,51\end{array}$ & $\begin{array}{l}1647,00 \\
1203,00\end{array}$ & 500,00 & $0,001^{*}$ \\
\hline
\end{tabular}

Notes: $\mathrm{BT}_{1}=$ sitting to standing; $\mathrm{BT}_{2}=$ standing unsupported; $\mathrm{BT}_{3}=$ sitting unsupported; $\mathrm{BT}_{4}=$ standing to sitting; $\mathrm{BT}_{5}=$ transfers; $\mathrm{BT}_{6}=$ standing with eyes closed; $\mathrm{BT}_{7}=$ standing with feet together; $\mathrm{BT}_{8}=$ reaching forward with outstretched $\operatorname{arm} ; \mathrm{BT}_{9}=$ retrieving object from floor; $\mathrm{BT}_{10}=$ turning to look behind; $\mathrm{BT}_{11}=$ turning 360 degrees; $\mathrm{BT}_{12}=$ placing alternate foot on stool; $\mathrm{BT}_{13}=$ standing with one foot in front; $\mathrm{BT}_{14}=$ standing with one foot. * = significant

There was a significant improvement of BBS total score at the exercise group compared to the control group after statistic analysis using Mann Whitney test (table 4, figure 2).
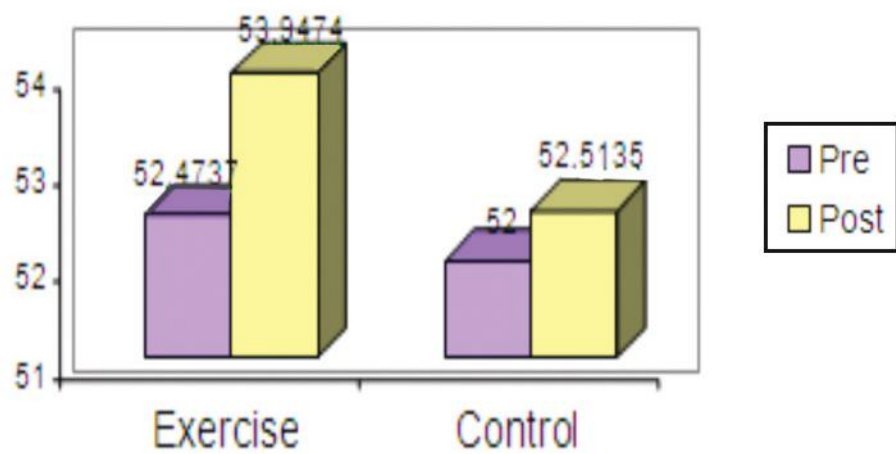

Figure 2. Mean of BBS Improvement 
Table 4. Mean of BBS Improvement

\begin{tabular}{lcccc}
\hline & \multicolumn{4}{c}{$\begin{array}{c}\text { Berg Balance Scale (BBS) } \\
\text { improvement }\end{array}$} \\
\cline { 2 - 5 } & $\begin{array}{c}\text { Mean of } \\
\text { Rank }\end{array}$ & $\begin{array}{c}\text { Sum of } \\
\text { Rank }\end{array}$ & $\begin{array}{c}\text { Mann- } \\
\text { Whitney }\end{array}$ & P \\
& & & $\boldsymbol{U}$ & \\
\hline Exercise & 44.62 & 1695.50 & 451.50 & $0.02^{*}$ \\
Control & 31.20 & 1154.50 & & \\
\hline
\end{tabular}

Sickness Impact Profile (SIP)

At the beginning of the study, quality of life parameters which were based on SIP of both groups were not different significantly.

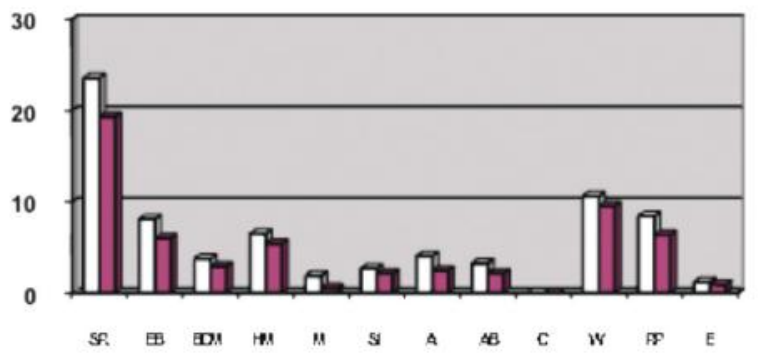

口Control Pre $\mathbf{c}$ Control Post

Figure 3. Mean SIP Parameters in the Control Group.

Statistic analysis showed no significant improvement of SIP parameter in pre and post intervention of the control group.

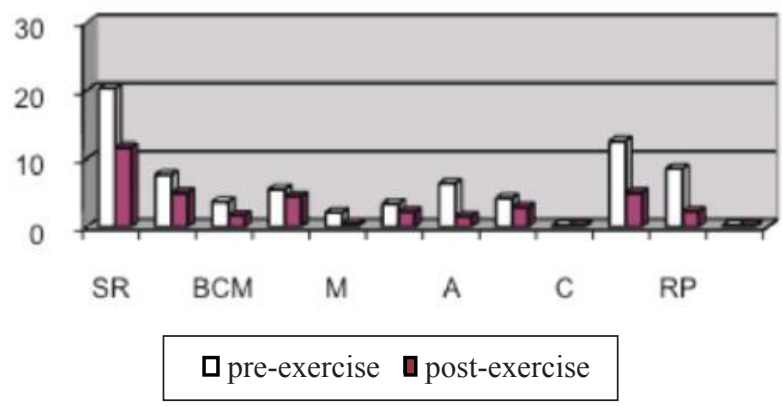

Figure 4. Mean SIP Parameter in the Exercise Group 
Figure 3 and 4 showed improvement in almost all SIP parameters in the exercise and control group after study.

If we compared the improvement of SIP parameter in both groups using Chi Square test, we can see significant improvement in the exercise group in 4 parameters: SR (sleep and rest), BCM (body care and movement), A (ambulation), W (work). Parameters which improved but insignificant were $\mathrm{E}$ (eat), HM (home management), RP (recreation and pastime), M (mobility), EB (emotional behavior), $\mathrm{AB}$ (affective behavior), SI (social interaction), $\mathrm{C}$ (communication).

Table 5. Percentage of Improvement in SIP Parameters Between the Two Groups

\begin{tabular}{lccccc}
\hline Para-meter & \multicolumn{2}{c}{ Exercise } & \multicolumn{2}{c}{ Control } \\
& $\begin{array}{c}\text { No } \\
\text { Improvement }\end{array}$ & $\begin{array}{c}\text { Improve } \\
\text { ment }\end{array}$ & $\begin{array}{c}\text { No } \\
\text { Improvement }\end{array}$ & $\begin{array}{c}\text { Improve } \\
\text { ment }\end{array}$ & p \\
& & & & & \\
\hline SR & 47,4 & 52,6 & 70,3 & 29,7 & $0,044^{*}$ \\
EB & 76,3 & 23,7 & 81,1 & 18,9 & 0,615 \\
BCM & 55,3 & 44,7 & 81,1 & 18,9 & $0,017^{*}$ \\
HM & 89,5 & 10,5 & 89,2 & 10,8 & 0,968 \\
M & 86,8 & 13,2 & 86,5 & 13,5 & 0,694 \\
SI & 76,3 & 23,7 & 89,2 & 10,8 & 0,141 \\
A & 42,1 & 57,9 & 81,1 & 18,9 & $0,001^{*}$ \\
AB & 86,8 & 13,2 & 89,2 & 10,8 & 0,754 \\
C & 97,4 & 2,6 & 100,0 & 0,0 & 0,368 \\
W & 28,9 & 71,1 & 81,1 & 18,9 & $0,000^{*}$ \\
RP & 57,9 & 42,1 & 62,2 & 37,8 & 0,706 \\
E & 100,0 & 0,0 & 97,3 & 2,7 & 0,308 \\
\hline
\end{tabular}

Notes: parameter sleep and rest (SR), work (W), body care and movement (BCM), ambulation (A), eat (E), home management (HM), recreation and pastime (RP), mobility (M), emotional behavior (EB), affective behavior (AB), social interaction (SI), communication (C). * = significant $\mathrm{p}<0,05$

\section{Correlation Test}

We continued the analysis using correlation test of Pearson Correlation to see any relationship between functional balance improvement (BBS) with SIP Parameters improvement (SR, BCM, A, W).

Table 6. Correlation Test between Improvement of BBS and SIP Parameters (SR, BCM, A, and W)

\begin{tabular}{ccc}
\hline Improvement & $\begin{array}{c}\text { Correlation } \\
\text { Koeficient }\end{array}$ & $\mathbf{p}$ \\
\hline BBS - SR & 0,945 & $0,000^{*}$ \\
BBS - BCM & 0,996 & $0,000^{*}$ \\
BBS - A & 0,986 & $0,000^{*}$ \\
BBS - W & 0,971 & $0,000^{*}$ \\
\hline
\end{tabular}

* Significant correl tion at 0,01 
The result of correlation test showed significant correlation between functional balance and SIP Parameters improvement (table $6)$.

\section{DISCUSSION}

Regular physical exercise have been known to be a treatment part of patients with type $2 \mathrm{DM}$. Regular exercise can improve insulin sensitivity and help lowering and maintain body weight in obese patient. Physical exersice also can control blood sugar level and improving lipid profile and A1c. Regular physical exercise can also have psychological advantages of lowering anxiety level, gaining happiness and obtaining self confidence. Quality of life may also improved by exercise. ${ }^{3,4}$

Indonesian Diabetic Exercise which was developed by Persatuan Diabetes Indonesia (Persadia) since 2002 was a kind of low impact aerobic exercise characterized by fun and enjoyable rhythmic motion, which can be done by all age groups, and hopefully may attract group enthusiasm among diabetic clubs. ${ }^{4}$ This exercise have been done routinely in Endocrinology Section Department of Internal Medicine Dr Soetomo General Hospital Surabaya.

\section{Patient General Characteristic}

In this study, mean ages of the subjects were between 55-57 years old. This showed that type 2 This is according to the fact that Diabetes Mellitus or also was called non insulin dependent diabetes mellitus (NIDDM) usually affected adult and old people, which was linked with decrease of cell sensitivity to insulin. It is suggested that sport or exercises were needed to increase cell sensitivity to insulin. . $^{3,4,6,8}$

Gender proportion of the subjects enrolled in this study showed that female is more dominant than male.

Mean period of suffering patient DM on both groups is between 7,43-7,80 years. This showed that DM is a chronic disease which needs continuous regular treatment in order to avoid acute complication like diabetic ketoacidosis, non ketotic hyperosmolar and hypoglycemia, and also chronic complication like macroangiopathy, microangiopathy, and neuropathy. ${ }^{1,6}$

\begin{abstract}
A1c level
After intervention, there was a significant improvement in A1c level in the exercise group compared with worsening in the control group. This result showed that routine diabetic exercise may improve Alc level. Worsening in Alc level in the control group might be caused by inadequate control of blood glucose level such as inadequate individual exercise, control of low sugar diet and lack of obidience of consuming oral anti diabetic drug (OAD).
\end{abstract}

\section{Berg Balance Scale (BBS)}

After three months of intervention, there were significant improvement in $\mathrm{BT}_{8}$ (reaching forward with outstretched arm) and $\mathrm{BT}_{14}$ (standing on one foot). Statistical analysis in total BBS also showed significant improvement in the exercise group. This result showed that routine diabetic exercise, generally may improve functional balance in type $2 \mathrm{DM}$ patient.

Diabetic neuropathy, one of the most frequent diabetic complication, may caused bilateral somatosensoric information loss in extremities. Somatosensoric defisits in legs may result in functional instability. That's why patient with diabetic neuropathy have a higher risk of fall in certain complicated daily activities. ${ }^{1,9}$

Ability to mantain balance is based on efficient detection and information integration from vestibular, visual and somatosensoric system. Dysfunction in one of these three sensoric systems (which might collide with other perceptive system) causing spatial disorientation, various degrees of unsteadiness or imbalance. ${ }^{10,11}$

Routine diabetic exercise may improve A1c level which in turn may decrease polyol pathway, non enzimatic glication and oxidative stress. This may result in increasing nitric oxide (NO) production and decreasing NO demand. NO is a strong vasodilator that may improve endoneural circulation which in turn may result in neural function improvement. Finally neural function improvement will result in functional balance improvement while simultaneously 
improve the quality of life.

\section{Sickness Impact Profile (SIP)}

In simple words, quality of life is defined as one's ability to perform one's life function normally in society in one's own perception. Specificly, quality of life shows many social states and one's health components, which is more subjective than objective..$^{10,11,15}$

Maintaining quality of life is one of the main goals of DM treatment, because: ${ }^{10,11} \mathrm{DM}$ is a chronic disease which cannot be curred completely, but if can be controlled, it can postpone or hinder physical complain due to acute and chronic complications. Low quality of life and psychological problems can worsen metabolic problems directly by stress and hormonal reaction or indirectly from bad compliance.

So, besides good metabolic control, DM patients also need a good quality of life. Poor quality of life may worsen metabolic function. ${ }^{15,16,17}$

Sickness Impact Profile (SIP) is one instrument which has been tested for its validity and reliability on measuring quality of life in chronic patients, as for diabetes mellitus, cardiovasculer, degenerative and malignancy. ${ }^{18}$

Our study showed that after doing diabetic exercise regularly 3 times a week for 3 months, all SIP parameters improved. Statistic analysis showed that significant improvement occurred in 4 from the total 12 parameters measured: sleep and rest (SR), body care and movement (BCM), and ambulation (A), work (W). This may happen because of the subjectivity of the quality of life measurement and the length of study which only 3 months, so it might be not enough to improve all physical and psychological components.

Further study with larger and more uniform samples, and longer time may be needed to obtain much more optimal result.

There is other positive impact from diabetic exercise in which the patients may gather together with the peer group, socialize, sharing experience and information that finally will result in lower anxiety level, increase self confidence, and indirectly improve their quality of life.

\section{CONCLUSIONS}

Diabetic exercise can improve Alc level, functional balance, and several quality of life parameters such as sleep and rest, work, body care and movement, and ambulation.

The improvement of functional balance has a correlation with quality of life parameters mentioned above.

More socialization may be needed to inform the benefit of diabetic exercise in improving the quality of life beside the physical benefits that already known widely.

\section{REFERENCE}

1. Askandar T. Diabetes Mellitus: Rekapitulasi. Askandar T, editor. Konas III Persatuan Diabetes Indonesia; 1995 Oct; Surabaya;1995.

2. Supartondo. Pengelolaan Pasien Diabetes Mellitus Tidak Tergantung Insulin (DMTTI). Konsensus di Indonesia. Askandar, editor. Konas III Persatuan Diabetes Indonesia; 1995 Oct ;Surabaya; 1995.

3. Sherman AL, Echeverry D. Diabetic neuropathy [internet]. 2004 [cited 2005 July 15]. Available from: http://www. emedicine.com.

4. Low PA. Pathogenesis of Diabetic Neuropathy. In: Joslin's Diabetes mellitus. $14^{\text {th }}$ ed. Philadelphia: Lippincott Williams \& Wilkins;2005.p.839-51.

5. Steppel JH, Horton ES. Exercise in Patients with Diabetes Mellitus. In: Joslin's Diabetes mellitus. $14^{\text {th }}$ ed. Philadelphia: Lippincott Williams \& Wilkins; 2005.p. 650-7.

6. Mardi S, Utoyo S. Olah Raga pada Penderita Diabetes Mellitus. Senam diabetes Indonesia Persatuan Diabetes Indonesia Seri 3; Yayasan Diabetes Indonesia; Jakarta; Juli 2006.

7. Anonim: Medical Statistics Online help: Sample size \& power for clinical trials.

8. Soetardjo. Diagnosis dan Klasifikasi Diabetes Melitus. In: Buku Ajar Ilmu Penyakit Dalam. $2^{\text {nd }}$ ed. Jakarta: Balai 
Penerbit FKUI; 1991.p.378-360.

9. Konsensus Pengelolaan dan Pencegahan Diabetes Melitus Tipe 2 di Indonesia 2006; Perkumpulan Endokrinologi Indonesia (PERKENI).

10. Daubney ME, Culham EG. LowerExtremity Muscle Force and Balance Performance in Adults Aged 65 Years and Older. Physical Therapy. 1999;79(12):1177-85.

11. Felsenthal G, Lehman JA, Stein BD. Principles of Geriatric Rehabilitation. In: Braddom RL, Buschbacher RM, Dumitru D, Johnson EW, Matthews DJ, Sinaki M, editors. Physical Medicine and Rehabilitation; $2^{\text {nd }}$ ed. Philadelphia: W.B. Saunders Company;2000. p.1343-67.

12. Hendromartono. Neuropati Diabetik Patogenesis dan Penatalaksanaan. Update On Neurology 2002; Surabaya: Airlangga University Press.p.25-40.

13. Tomlinson DR. Pathogenesis of Neuropathy. In: Pickup JC, William G, editors. Textbook of Diabetes vol 2. $3^{\text {rd }}$ ed. Massachussets: Blackwell Science; 2003.p.50.1-50.9.

14. Windebank AJ, Felmand EL. Diabetes and The Nervous System. In: Aminoff MJ, editor. Neurology and general medicine. $3^{\text {rd }}$ ed. New York: Churchill Livingstone; 2001.p.341-353.

15. Steinberg FU. Disorders of Mobility, Balance, and Gait. In: Felsenthal G, Garrison SJ, editors. Rehabilitation of The Aging and Elderly Patient. Baltimore: William \& Wilkins;1994.p. 243-51.

16. Wood-Dauphine S, Berg K, Bravo G, William JI. The Balance Scale: Responding to clinically meaningful changes. Can J Rehabil. 1997;10:35-50.

17. Wita IW. Program Intervensi Terpadu Mengendalikan FaktorResiko Koroner dan Meningkatkan Kualitas Hidup Pasca Infark Miokard Akut [dissertation]. Surabaya: Airlangga University; 1992.

18. Coffey JT, Brandle M, Zhou H, Marriott D, Burke R, Tabaei BP, et al.Valuing HealthRelated Quality of Life in Diabetes. Diabetes Care. 2002; 25: 2238-42.
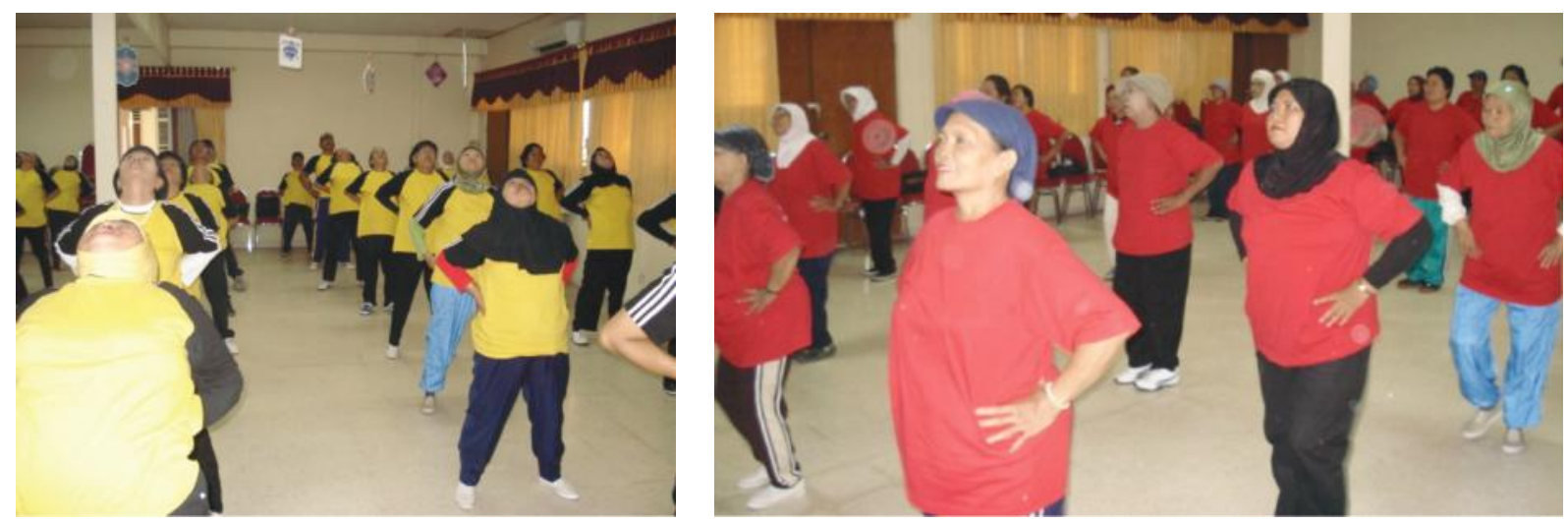